\title{
Integrated Geologic, Geochemical, and Geophysical Studies of Big Bend National Park, Texas
}

Recently completed studies of Big Bend National Park provide new information on the following topics:

- Effect of historical mercury mining in and near the park

- Origin and composition of metals in ground and surface water

- History of volcanic and intrusive activity

- Complex geologic history
National Park Service (NPS), USGS scientists from the Mineral Resources and National Cooperative Geologic Mapping Programs have carried out (1) studies of mercury contamination at sites of past mercury mining in and adjacent to BBNP; (2) research of volcanic stratigraphy and geochronology (dating) of intrusive and extrusive igneous rocks; (3) evaluations of surface and subsurface water quality and resources, as well as processes related to rock alteration in the park; (4) characterization studies of geophysical properties of the surface and subsurface geology in BBNP; and (5) mapping of the surface geology in order to produce a new geologic map of the park. This fact sheet describes results of some of the research by USGS scientists working in BBNP.

\section{Contaminant Studies of Inactive Mercury Mines}

One of the primary objectives of research in BBNP involves studies to understand potential contamination from mercury mines in and around the park (fig. 1). Mercury has no known biological function and is toxic to all organisms, including humans. Presently, no mines are operating in the area; however, total mercury production ranks the Terlingua district as the third largest mercury mining region in the United States. The effect of runoff from mines acres $\left(3,242 \mathrm{~km}^{2}\right)$ and was established in 1944 through a transfer of land from the State of Texas to the United States. The park is located along a 118-mi (190-km) stretch of the Rio Grande at the United States border with Mexico. The park is situated in the Chihuahuan Desert, and this desert ecosystem displays enormous beauty including mountain and basin environments with an extraordinary biological diversity of native plants and animals. The park is home to a variety of flora and fauna including more than 1,200 species of plants, more than 450 species of birds, 56 species of reptiles, and 75 species of mammals. Geologic features in BBNP provide opportunities to study the formation processes of sedimentary and igneous rocks, as well as opportunities to investigate Cretaceous and Tertiary fossils. Mineral deposits in and around BBNP contain commodities such as mercury, uranium, and fluorite, but of these, the only significant mining has been for mercury. The Chisos Mountains reach an altitude of 7,832 ft (2,387 m) and are considered the southernmost mountain range in the United States. More than 350,000 tourists visit BBNP each year.

The U.S. Geological Survey (USGS) began a 5-year project in 2003 with the objective of studying a number of broad and diverse geologic, geochemical, and geophysical topics in BBNP. Working cooperatively with the

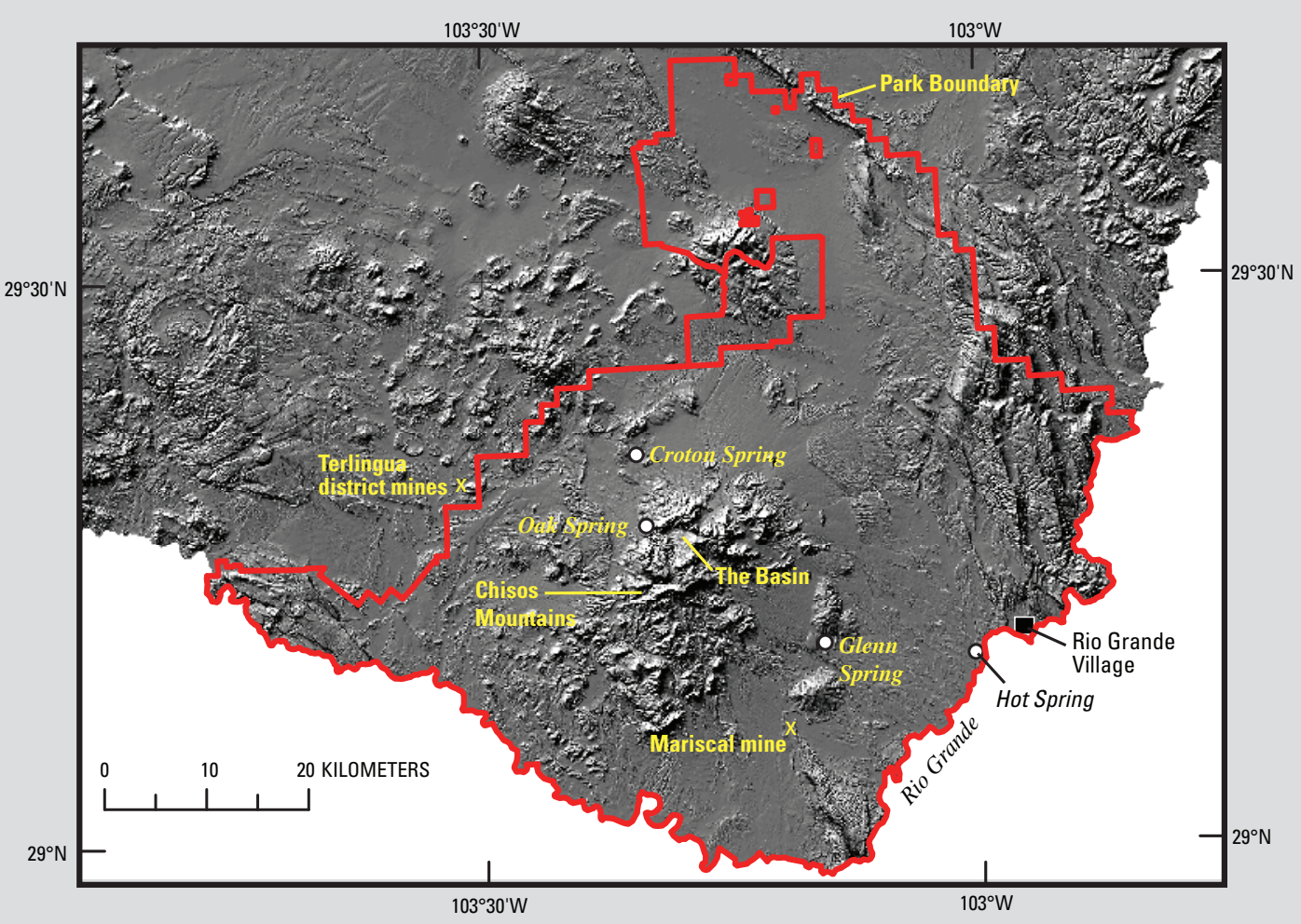

Figure 1. Shaded relief map of the Big Bend area showing the outline (in red) of Big Bend National Park and locations of areas studied by the USGS. The Terlingua district mines shown here produced more than $5,000 \mathrm{t}$ of mercury during the 1890 s to 1970 s; they were the subject of recent USGS studies. 
located inside and just outside the park boundary is a concern for both wildlife and humans because mercury is highly concentrated around the abandoned mines, and water draining the mines enters streams that are part of local ecosystems. The USGS has been measuring mercury concentrations in mine waste, sediment, water, and air throughout BBNP to address potential mercury contamination around these mercury mines.

The Mariscal mine, the only mine that produced mercury in BBNP, has been the subject of much of the work by the USGS on this project. One of the smaller mines in the Terlingua mercury district and active from about 1900 to 1943, the Mariscal mine was included in BBNP when the park was established in 1944. Because Mariscal is located inside BBNP, tourists often visit this site. The volume of mine waste at the Mariscal mine is estimated at about $39,200 \mathrm{yd}^{3}\left(30,000 \mathrm{~m}^{3}\right)$, and the concentration of mercury in samples of mine waste is as high as $150 \mu \mathrm{g} / \mathrm{g}$ (micrograms per gram), several orders of magnitude higher than that typically found elsewhere in uncontaminated soil in BBNP. Minor mine waste was observed in a stream channel (Fresno Creek) draining the mine, but the concentration of mercury in stream sediment collected greater than $0.6 \mathrm{mi}(1 \mathrm{~km})$ from Mariscal (fig. 2) is similar to that in uncontaminated regional baseline sediment (Gray and others, 2006). No mine-water runoff was observed draining Mariscal during studies from 2003-2007. Although mercury and methylmercury concentrations are locally elevated in some mine waste samples, little mercury appears to be exported from these mercury mines in stream sediment or water primarily due to the arid climate and lack of precipitation and mine runoff in this region. These studies indicate that conversion of inorganic mercury to highly toxic organic mercury forms (methylmercury) is also low in this arid climate setting.

\section{Studies of Igneous Rocks}

Extrusive and intrusive igneous rocks, known to be the source of some mineral occurrences, were the subject of detailed studies in BBNP. A broad spectrum of igneous rocks-including structurally controlled dikes (cross-cutting bedding), shallow intrusive bodies, and large ash-flow tuffs, which have produced calderas (large, generally circular volcanic depressions formed by extrusion of magma and subsequent collapse of surrounding ground) - dominate the landscape. Dagger Flats and Pine Canyon caldera were identified as two sites for detailed studies to understand how the igneous rocks were formed because they are associated to some degree with extensive fossil hydrothermal systems (figs. 3 and 4).

Low northwest-trending hills in the Dagger Flats area are bounded by northwest-trending faults cored with thick sills that were intruded along bedding and are capped by Cretaceous sedimentary rocks. Sill and associated magmatic hydrothermal solutions that intruded into marine sedimentary rock resulted in formation of skarns at Dagger Flats. Sills at Dagger Flats form a well-defined northwest-trending body that is about 9-14 mi (15-22 $\mathrm{km}$ ) long by $3 \mathrm{mi}(5 \mathrm{~km})$ wide, which is comparable to, or larger than, adjacent intrusive bodies in the McKinney Hills and the Rosillos Mountains. The Dagger Flats intrusive complex is slightly larger than the intrusive bodies associated with the Pine Canyon caldera. High-precision radiometric dates (using isotopes of argon, ${ }^{40} \mathrm{Ar} /{ }^{39} \mathrm{Ar}$ ) of the Dagger Flats sills indicate that these bodies were intruded from $32.47 \pm 0.41$ to $30.95 \pm 0.61$ Ma during a 1.5 -millionyear interval beginning at about 31 million years ago (Ma), which is contemporaneous with peak intrusive and volcanic activity less than $6 \mathrm{mi}(10 \mathrm{~km})$ to the south at the Pine Canyon caldera. Radiometric dates in the Pine Canyon area indicate that igneous activity resulted in formation of a caldera that ranged in age from $32.22 \pm 0.12$ to $30.86 \pm 0.41 \mathrm{Ma}$. Field observations coupled with dating of rocks at Dagger Flats and Pine Canyon contributed to the understanding of the history of igneous rocks in BBNP.

\section{Surface and Subsurface Water Quality and Resources}

In the desert climate of BBNP, water quality and water supply are persistent issues. Geochemical studies were designed to evaluate the sources, transport, and dispersion of metals in surface water, ground water, and active hot springs. Monitoring of major-element,
$A$.

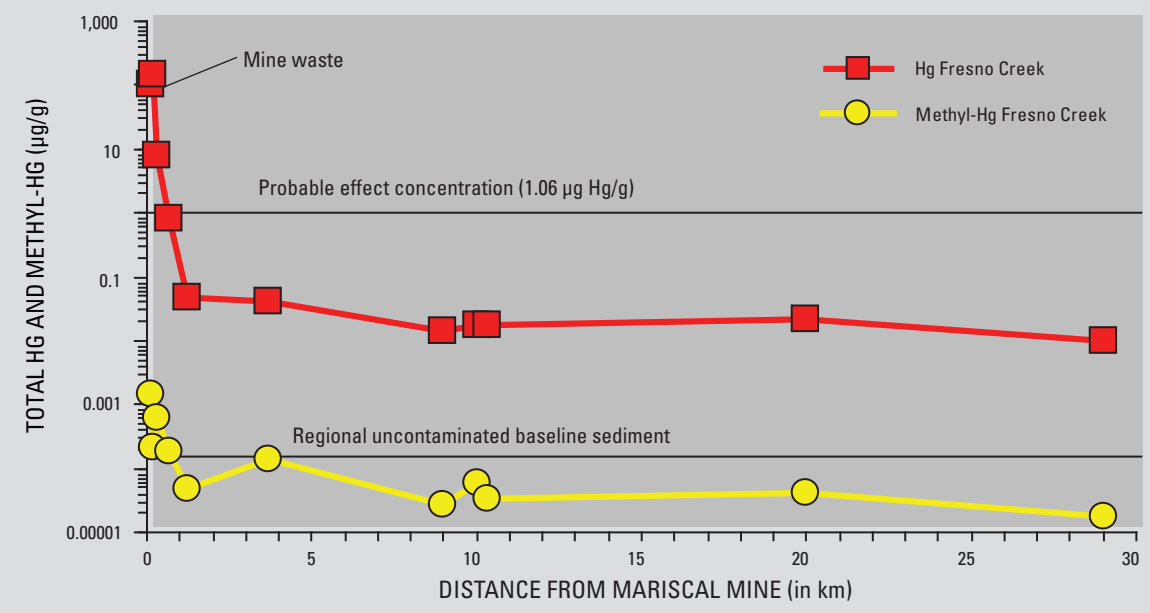

$B$.

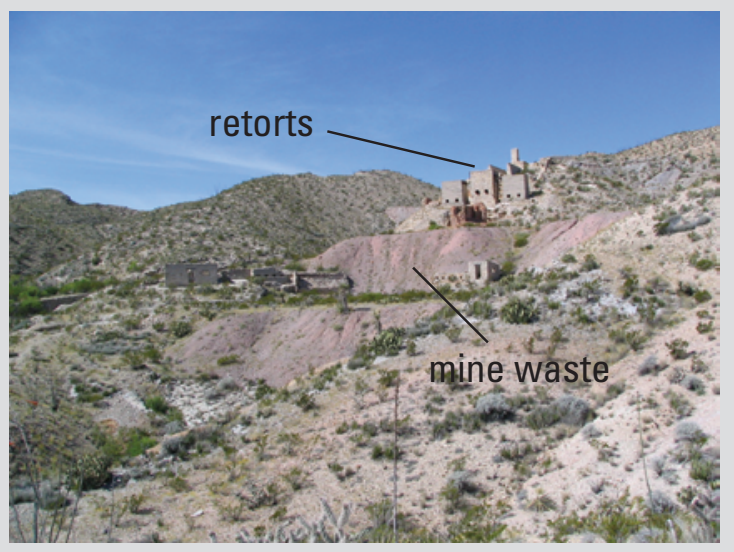

Figure 2. A. Stream sediment collected downstream from the Mariscal mine, Texas, shows rapid dispersion of total mercury (Hg) and methylmercury (methyl- $\mathrm{Hg}$ ). Results show that total mercury concentrations decrease in sediment collected more than $1 \mathrm{~km}$ from the mine and are below the probable effect concentration for mercury, the concentration where harmful effects are likely in sediment-dwelling organisms. Methylmercury concentrations in stream sediment samples were generally below that found in regional uncontaminated baselines. Although mercury concentrations were elevated in mine waste, the concentrations of methylmercury were generally low in the ecosystems downstream because conditions for transformation to methylmercury are unfavorable in this hot and dry desert climate. $B$. View of the Mariscal mercury mine located in Big Bend National Park. 


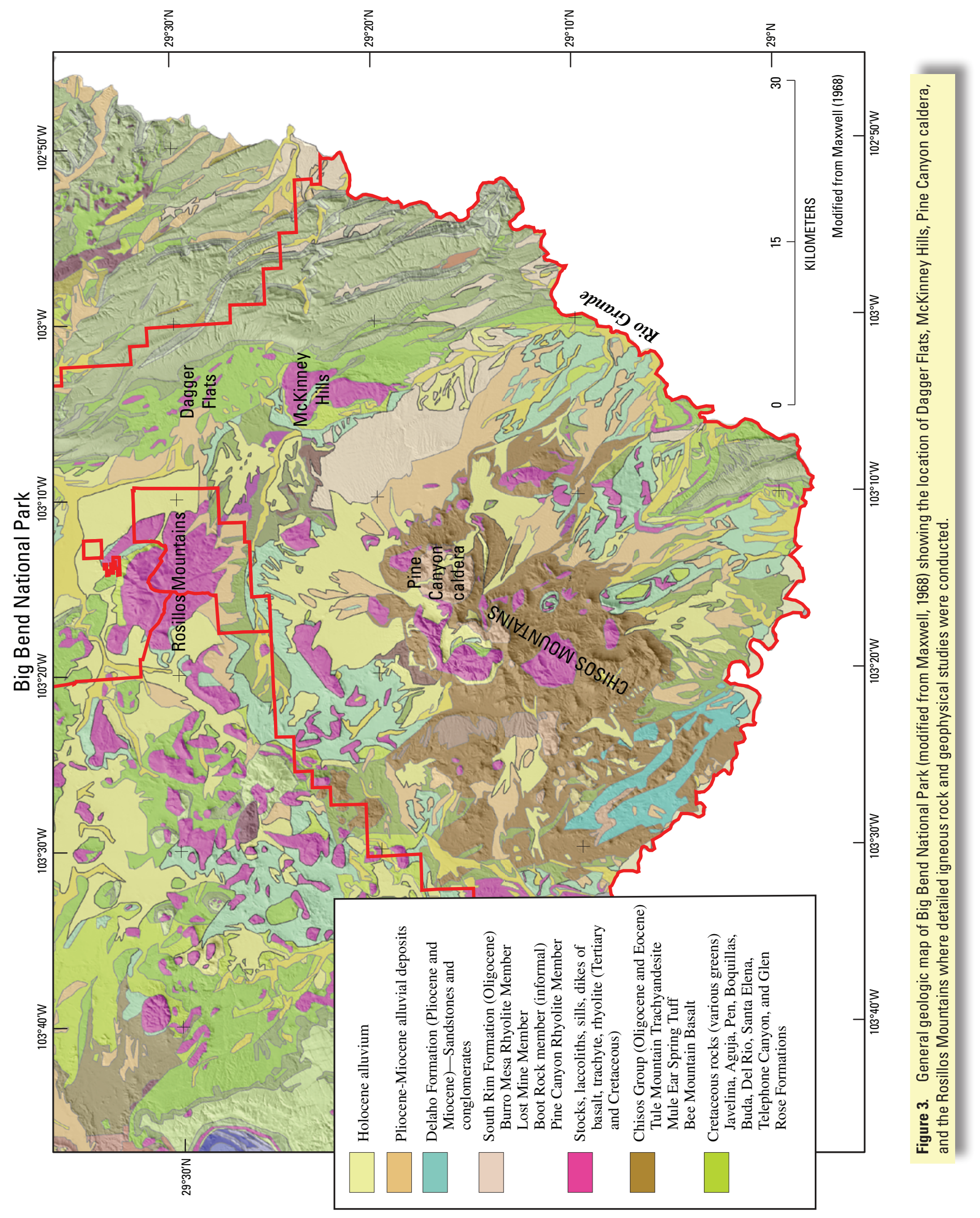




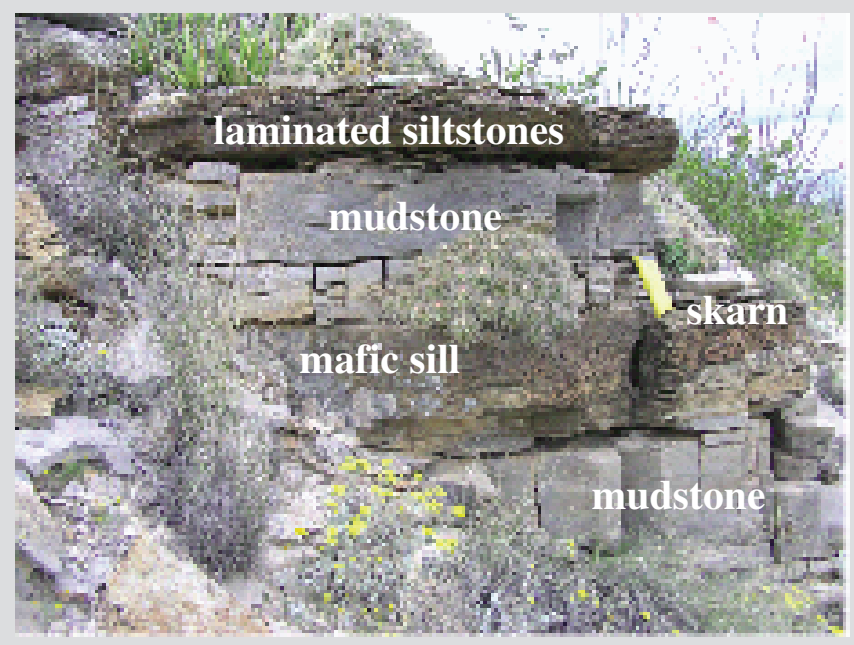

Figure 4. At Dagger Flats, sedimentary rocks were intruded by sills that produced associated mineralized rocks forming a low-grade skarn deposit containing quartz, pyrite, wollastonite, prehnite, and grossular garnet. The skarn deposits have formed in the caprock directly above the sills, which are composed primarily of mafic rocks (containing magnesium and iron-bearing minerals). The movement of magmatic hydrothermal solutions into marine sedimentary rock resulted in the skarn formation.

trace-element, and isotopic compositions in water helps to establish base lines against which future trends related to climate change, drought, and other regional events can be measured. Water samples were collected from a broad range of geologic and geographic settings in BBNP-including the Rio Grande, several hot and cold springs, and water wells - to characterize the water chemistry, and to more thoroughly understand the age, flow path, and host lithology of surface and ground water.

Potentially toxic trace metals in various spring-water samples range in concentration as follows: copper $(<0.5-23 \mu \mathrm{g} / \mathrm{L}$, micrograms per liter), lead $(<0.05-3.2 \mu \mathrm{g} / \mathrm{L})$, cadmium $(<0.02-$ $3.5 \mu \mathrm{g} / \mathrm{L})$, thallium $(<0.05-0.68 \mu \mathrm{g} / \mathrm{L})$, selenium (0.81-11 $\mu \mathrm{g} / \mathrm{L})$, and uranium $(0.14-29 \mu \mathrm{g} / \mathrm{L})$; these data provide assurance that these trace metals are all below drinking water maximum contaminant levels (MCLs) established by the U.S. Environmental Protection Agency. Water sources throughout BBNP are also generally below the MCL for arsenic $(10 \mu \mathrm{g} / \mathrm{L})$ and fluoride $(4.0 \mu \mathrm{g} / \mathrm{L})$. However, potential water quality problems were found in water collected from Glenn Spring containing $16 \mu \mathrm{g} / \mathrm{L}$ arsenic, the hot spring west of Rio Grande Village with $16 \mu \mathrm{g} / \mathrm{L}$ arsenic, and Croton Spring containing $19 \mu \mathrm{g} / \mathrm{L}$ fluoride, but these are not used as drinking water sources in BBNP. Drinking water produced from wells at Rio Grande Village contains a significant component of hot spring water, but does not exceed the MCL for arsenic or other elements. Additional studies are underway to more thoroughly address the source of such contaminants, but data suggest that meteoric water (of recent atmospheric origin) may leach some potentially toxic metals during circulation and interaction with surrounding altered and mineralized limestone and volcanic rocks. Using stable isotopic tracer techniques, it is possible to understand unique interactions of meteoric water with surrounding rocks. Stable isotopes indicate that all BBNP water is meteoric in origin, and evaporation produces a significant range of oxygen and hydrogen isotope values (fig. 5). Hot and cold spring water samples are shifted from the global meteoric water line to slightly higher oxygen and hydrogen isotopic compositions due to water-rock reactions in the subsurface and (or) minor evaporation at the surface.

Evidence of nuclear bomb tests in the 1950s and 1960s can be used to date various types of water. Tritium is a radioactive isotope of hydrogen produced in abundance during nuclear bomb testing. Tritium enters ground water as infiltrating precipitation, then decays with time to another isotope, helium-3. Because the rate of radioactive decay is known, tritium and helium- 3 can be used to date ground water younger than about 50 years, as well as to determine the approximate fractions of old water ( $>50$ years old) and young water ( $<50$ years old) in mixed age samples. In addition, noble gas concentrations (helium, neon, argon, krypton, xenon, and radon) can be used to calculate the temperature and elevation of ground-water recharge. Water collected from the hot spring west of Rio Grande Village has circulated deeply, probably along fault zones, and the water was geothermally heated during this deep circulation. Oak Spring water, which is the water supply for The Basin (see fig. 1), originates in The Basin and probably flows down along fractures and faults to the topographically lower Oak Spring. These new studies indicate that most ground water utilized as drinking water in BBNP is a mixture of young water, and an older, more deeply circulating water component.

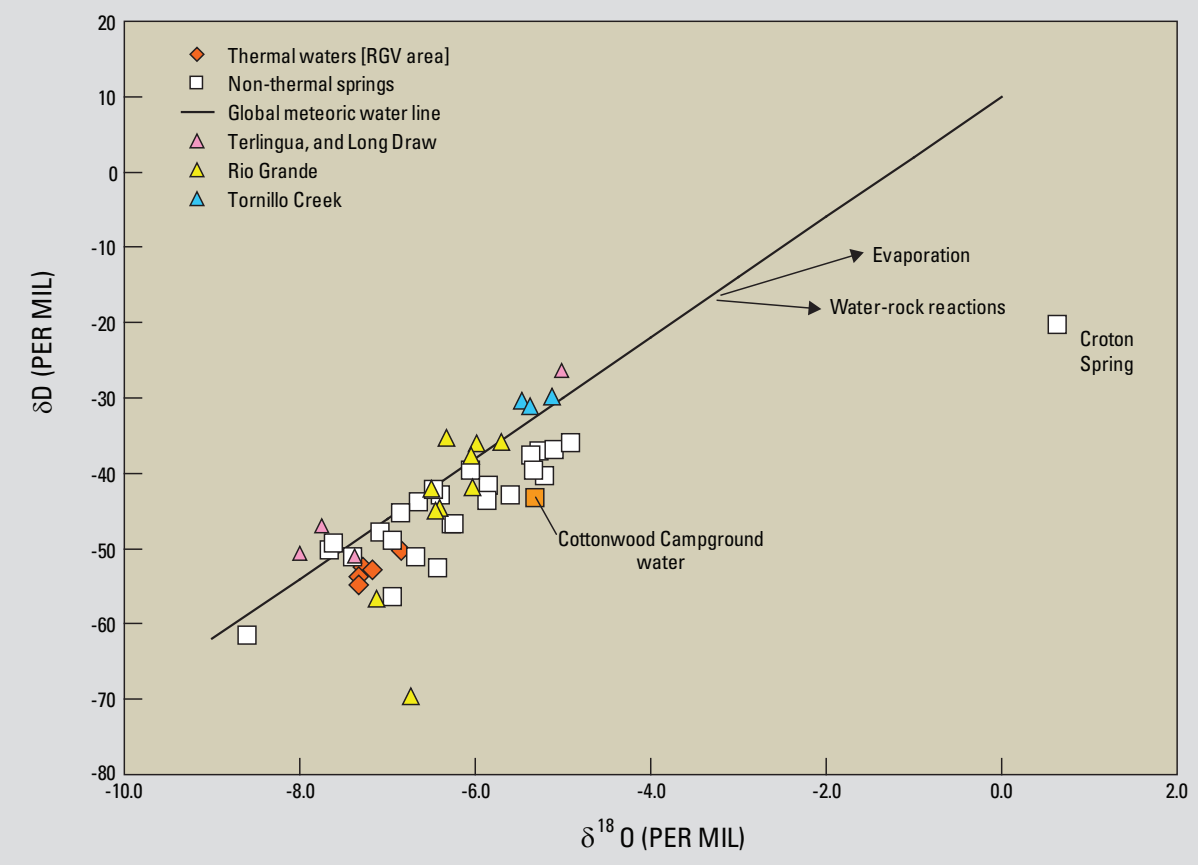

Figure 5. Hydrogen $(\delta D)$ versus oxygen isotope $\left(\delta^{18} 0\right)$ values showing domination by meteoric waters. $\delta$ is conventionally defined as the ratio of isotopes of an element compared against a standard, such as standard mean ocean water. Many hot and cold spring waters (which commonly occur in pools at the surface) are shifted off the meteoric water line, probably due to evaporation. Rio Grande water is generally less evaporated than springs. Croton Spring is highly evaporated water. 


\section{Geophysical Studies}

Geophysical studies in BBNP provided key information in the interpretation of the volcanic stratigraphy and geology of the park. The Pine Canyon Rhyolite Member of the South Rim Formation, the main unit in the Pine Canyon caldera, is shown by direct and indirect observations and modeling to be reversely magnetized (Drenth and Finn, in press). This conclusion is supported by a new ${ }^{40} \mathrm{Ar} /{ }^{39} \mathrm{Ar}$ age of $32.03 \pm 0.08 \mathrm{Ma}$, which corresponds to a time when the magnetic field of the Earth was reversed. Modeling of gravity and magnetic anomalies indicate that the Pine Canyon Rhyolite Member has lower magnetization intensities and densities in the southwestern portion of the caldera, possibly due to the effects of hydrothermal alteration (fig. 6). A geophysical magnetic high was found in this area, and it is interpreted as a broad laccolith (a planoconvex concordant igneous body with a flat bottom) that overlies the Pine Canyon caldera and surrounding Chisos Mountains region. This feature represents the largest intrusion (17-21 mi $(28-34 \mathrm{~km})$ diameter, 0.6-2.5 mi (1-4 km) thick, 168-720 $\mathrm{mi}^{3}$ (700-3,000 $\mathrm{km}^{3}$ ) in volume) in an area where relatively small laccoliths are found. The intrusion most likely represents a long-lived reservoir replenished by small batches of magma of varying composition as reflected in the variation of volcanic rocks in the Chisos Mountains. The intrusion may represent the easternmost occurrence of voluminous Tertiary magmatism in the southwestern United States.

Another geophysical study undertaken in collaboration with geologists mapping in BBNP was conducted around the Rosillos Mountains. This particular study integrated and interpreted aeromagnetic, radiometric, gravity, Landsat Enhanced Thematic
Mapper (ETM), and geologic mapping to produce a three-dimensional geologic map of the region and refine the surficial geologic mapping. Data sets were processed, and the geologic information was used to prepare a representation of the geology in three dimensions. A number of different data sets (Landsat ETM, aeromagnetic, and radiometric data) were used to distinguish surficial igneous units, provide clues to relative ages through magnetic reversals within the igneous rocks, and help define the geochemical composition of the igneous rocks. The aeromagnetic and gravity data were modeled to determine volumes of the intrusive rocks, as well as to investigate the structural offset of the main laccolith within the Rosillos Mountains. This modeling shows a variation in offset along a fault in the northern end of the Rosillos Mountains, which offsets the main intrusive body by nearly $500 \mathrm{~m}$; the offset decreases toward the south to only $200 \mathrm{~m}$.

\section{Geologic Mapping}

Current geologic mapping in BBNP is part of a large project designed to provide a new 1:100,000-scale map of the park because BBNP has not been mapped since the 1960s (Maxwell, 1968). USGS geologists cooperated with colleagues from academia and the NPS to identify and compile existing mapping, as well as provide new mapping where required. A portion of the new BBNP map compilation (fig. 7) illustrates the level of detail that will be portrayed on the new map. In addition to mapping BBNP, USGS geologists are also studying a number of research topics related to structural geology, tectonics, volcanology, petrology, stratigraphy, paleontology, and geomorphology of surficial deposits.

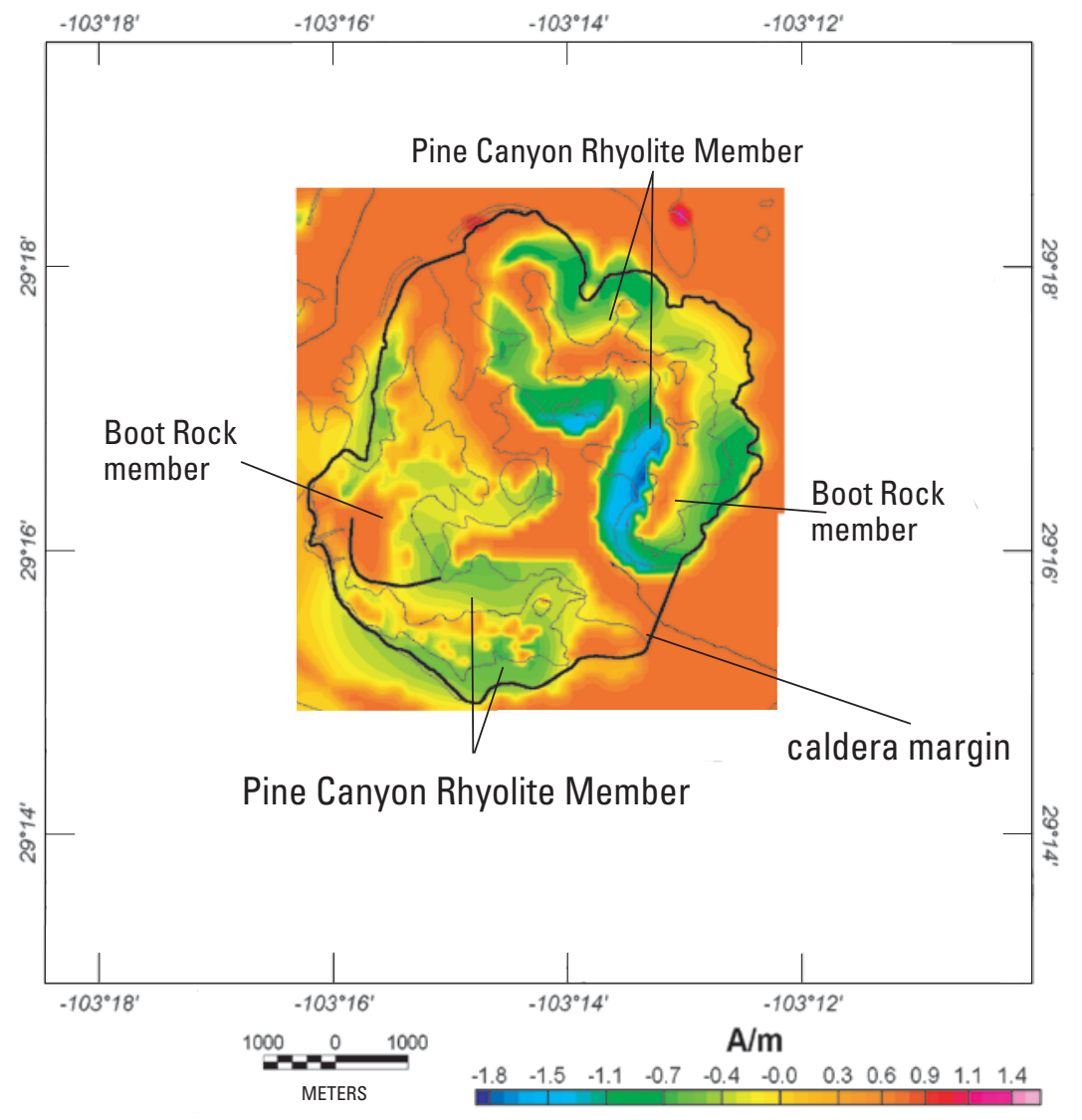

Figure 6. Surface magnetization map of the Pine Canyon caldera showing strong negative magnetizations (blue and green, indicating reversed polarity) assigned to the Pine Canyon Rhyolite Member of the South Rim Formation and weaker positive magnetizations (yellow and orange) assigned to the Boot Rock member, an informal member of the South Rim Formation. Geophysical studies were key to unraveling the geology of the Pine Canyon area. $\mathrm{A} / \mathrm{m}=$ ampere/meter. 


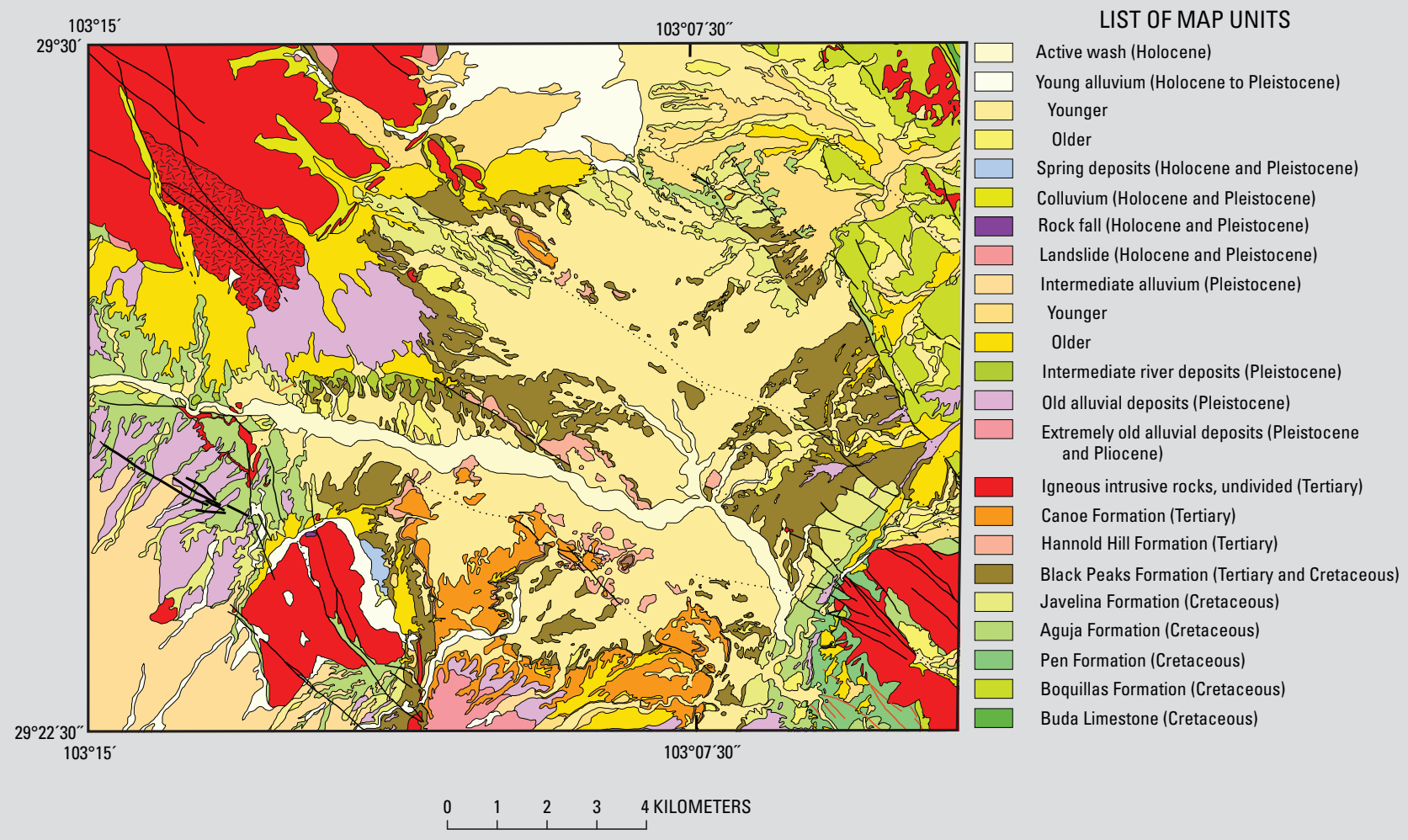

Figure 7. Preliminary geologic map compilation of parts of the Grapevine Hills and McKinney Springs quadrangles. Map represents compilation of new and pre-existing bedrock mapping and new surficial mapping for the new 1:100,000-scale Big Bend National Park geologic map.

\section{References Cited}

Gray, J.E., Hines, M.E., and Biester, H., 2006, Mercury methylation influenced by areas of past mercury mining in the Terlingua district, southwest Texas, USA: Applied Geochemistry, v. 21, no. 11, p. 1,940-1,954.

Drenth, B.J., and Finn, C.A., in press, Aeromagnetic mapping of the structure of Pine Canyon caldera and Chisos Mountains intrusion, Big Bend National Park, Texas: Geological Society of America Bulletin.

Maxwell, R.A., 1968, The Big Bend of the Rio Grande: Texas Bureau of Economic Geology Guidebook 7, 138 p.

\section{By John E. Gray, Carol A. Finn, Lisa A. Morgan, William R. Page, and Wayne C. Shank}

For more information contact:

John E. Gray

U.S. Geological Survey

P.O. Box 25046, MS 973

Denver, CO 80225

email: jgray@usgs.gov

Geochemical and geophysical data available on line at: http://minerals.cr.usgs.gov/ projects/big_bend/index.html 